\title{
Gotcha! \\ A Profile of Smuggling in International Trade
}

\author{
HELGE BERGER \\ VOLKER NITSCH
}

CESIFO WORKING PAPER NO. 2475

CATEgORY 7: TRAde Policy

NOVEMBER 2008

Presented at CESifo Venice Summer Institute 2008, Workshop on

'Illicit Trade AND GlobalisAtion'

\footnotetext{
An electronic version of the paper may be downloaded

- from the SSRN website: Www.SSRN.com

- from the RePEc website: $\quad$ www.RePEc.org

- from the CESifo website: www.CESifo-group.org/wp
} 


\title{
Gotcha! A Profile of Smuggling in International Trade
}

\begin{abstract}
This paper explores official trade data to identify patterns of smuggling in international trade. Our main measure of interest is the difference in matched partner trade statistics, i.e., the extent to which the recorded export value in the source country deviates from the reported import value in the destination country. Analyzing 4-digit product level data for the world's five largest importers for the period from 2002-2006, we find that the reporting gaps are highly correlated with the level of corruption in both partner countries. This finding supports the hypothesis that trade gaps partly represent smuggling activities.
\end{abstract}

JEL Code: D73, F14, F19, O17, O57.

Keywords: corruption, illicit, illegal, trade, statistics, tariffs.

\author{
Helge Berger \\ Free University Berlin \\ Economics Department \\ Boltzmannstrasse 20 \\ 14195 Berlin \\ Germany \\ helge.berger@fu-berlin.de
}

\author{
Volker Nitsch \\ ETH Zurich \\ KOF Swiss Economic Institute \\ Weinbergstrasse 35 \\ 8092 Zurich \\ Switzerland \\ nitsch@kof.ethz.ch
}

November 10, 2008

We thank Mohammad Reza Farzanegan, Andrey Stoyanov and participants at various conferences for helpful comments and Verena Arendt, Lena-Maria Dörfler and Svenja Hector for valuable research assistance. 


\section{Introduction}

In principle, international trade statistics should match so that a country's exports to a particular partner are identical to the partner's recorded imports from that supplier. In practice, however, these numbers differ, for various reasons. For instance, a major source of discrepancy is the conceptual difference in valuation. Exporting countries report the value of goods at the initial point of departure (fob), while import values refer to the value at the point of final destination, thereby including the costs of freight and insurance (cif). As a result, the cif/fob ratio has been frequently used in the literature as a measure of transportation costs. Limão and Venables (2001) provide a recent application of this approach; see Hummels and Lugovskyy (2006) for a detailed critique.

Apart from the different treatment of shipping costs, however, there are also other methodological difficulties when exploring matched partner trade statistics. For instance, the correct identification of the source or destination country might be a problem. When the country of final destination is not known at the time of exportation, the exporter declares the country of last shipment; the country of final destination, in contrast, classifies its imports by country of origin. Another potential issue of importance is timing. Since there are often notable time lags between the departure and arrival of a shipment (e.g., due to long-distance sea cargo, a delay in customs declaration or temporary storage in a warehouse), trade could be recorded in different calendar years. More importantly, statistical offices in the source and destination country may value goods at different prices and/or exchange rates. Finally, recorded trade on the commodity level may differ due to the omission of individual transactions in one of the partner countries (e.g., because of varying trade thresholds across countries), the exclusion of certain product groups in a country's trade statistics (such as military material or repair trade) or differences in commodity classification (e.g., a regrouping of a transaction into chapter 99 for reasons of confidentiality). In view of all these difficulties, the European Union, though aiming to reduce the declaration burden on businesses, still refrains from using mirror (single-flow) trade statistics. ${ }^{1}$

Most recently, Fisman and Wei (2007) have emphasized another possible explanation for the observed differences in matched partner trade statistics. They argue that the gap between exports and imports may (partly) reflect systematic (criminal) behavior by traders. In particular, they argue that for products with sharp export restrictions in the source country and no barriers to import in the destination country, traders have a strong incentive to underreport

\footnotetext{
${ }^{1}$ For an early attempt, see the European Commission's "Simpler Legislation for the Internal Market (SLIM)" initiative, which is documented at http://ec.europa.eu/internal_market/simplification/index_en.htm.
} 
exports (i.e., to smuggle the good out of the country), while properly declaring imports (because of no constraints for entry, in combination with the risk of seizure when there is false declaration). Analyzing trade gaps for a product category that is likely to display those characteristics, antiques of an age exceeding one hundred years (Harmonized System [HS] product code 9706), Fisman and Wei (2007) find that underreporting is indeed strongest for countries for which survey-based measures indicate a high level of corruption and, thus, ignorance of legal rules and procedures (also in trade) may be be relatively easy. Moreover, they find no such association for a product category with no (or less strict) restrictions for exportation, such as toys, scale models etc., puzzles, parts (HS code 9503), which appears reassuring.

In this paper, we examine the discrepancies in pair-wise trade statistics for a much broader set of product categories. In particular, we aim to identify countries that systematically underreport export activities in international trade statistics and, thus, apparently suffer strongly from smuggling. Further, we explore differences in trade gaps across individual product categories. This allows analyzing, for instance, whether there are products other than cultural objects that are prone to illicit trade. In sum, we develop a profile of smuggling that identifies both major source countries and important product categories for smuggling.

To preview our results, we find that pair-wise discrepancies in official trade statistics are highly correlated across both countries and products. Moreover, country-specific trade gaps are strongly associated with the level of corruption, especially in the source country. Also, product-specific trade gaps vary systematically with the level of protection in the destination country. Taken together, these findings suggest that at least part of the discrepancy in international trade figures is due to smuggling. ${ }^{2}$

The remainder of the paper is organized as follows. Section 2 briefly reviews the relevant literature on misreporting in trade. We then describe our methodology and the data, followed by a presentation of the empirical results. Section 5 summarizes our findings and concludes.

\footnotetext{
${ }^{2}$ In reality, customs offices already apply such profiles to assess risks. In the European Union, for example, a risk information form is used to exchange information among the customs administrations of member states; see http://ec.europa.eu/taxation_customs/customs/customs_controls/risk_management/implementi ng/index_en.htm. In Germany, a central office for risk analysis (Zentralstelle Risikoanalyse, ZORA) has been established in 2002; see http://www.bundesfinanzministerium.de/cln_06/nn_17844/DE/Aktuelles/Monatsbericht_des BMF/2006/englisch/060918agmb009.html.
} 


\section{Misinvoicing in Trade}

The finding that official trade statistics may suffer from misreporting and faked declarations is a well-known fact, not only to statisticians of international trade. Bhagwati (1964, 1967) provides an early economic discussion of incentives for misinvoicing in trade; Bhagwati and Hansen (1973) develop a trade model to examine the welfare effects of smuggling. Also, there are a number of papers that focus on regional experiences in the accuracy of trade statistics. Deardorff and Stolper (1990), among others, examine illegal trade in Africa; see also Yeats (1990). Baldwin (2006, pp. 57-61) provides an extensive discussion of problems in the collection of trade data in Europe, including a detailed description of fraudulent trade activities by criminals.

While Fisman and Wei (2007) focus on the strongest reason for misreporting exports, an outright export embargo, there are other incentives for underinvoicing exports or smuggling goods out of the country. A first group of reasons covers export restrictions in general. Apart from the prohibition of exports, there may be other, less strict hindrances to sales abroad, such as export taxes, export quotas or various regulatory hurdles. Misdescription or misdeclaration of cargo is an obvious solution to circumvent these trade restrictions.

Another set of reasons focuses on incentives to hide export sales. For instance, underreporting of exports allows firms to acquire foreign exchange that is not disclosed to national authorities; the foreign currency can then be freely used by exporters without complying with any controls and regulations (e.g., a potential option may be the sale of foreign currency in the parallel exchange rate market). Further, authorities may use information on firms' export activities to infer on their production. As a result, firms that seek to hide output (e.g., to evade domestic taxes) will automatically also seek to hide exports. Dabla-Norris, Gradstein and Inchauste (2008) provide a description of informal activities by firms.

Most importantly for our purposes, a number of papers have already shown that reporting incentives may have measurable effects on aggregate trade figures. Celasun and Rodrik (1989) argue that a sizable share of the increase in Turkish exports after 1980 is due to a change in invoicing practices of domestic entrepreneurs (in order to take advantage of generous export subsidies). Baldwin (2006) notes that in the early 2000s, the effect of VAT fraud on trade was so large that the United Kingdom had to restate its national accounts. More generally, McDonald (1985) provides several case studies on the size of trade data discrepancies for individual countries. 


\section{Methodology and Data}

Our main measure of interest is the difference in recorded trade flows between the exporting and the importing country. Following Fisman and Wei (2007), we define the reporting gap in official trade statistics as:

$$
\operatorname{Gap}^{\mathrm{k}}{ }_{\mathrm{ijt}}=\ln \left(1+\operatorname{Imports}_{\mathrm{jit}}^{\mathrm{k}}\right)-\ln \left(1+\text { Exports }^{\mathrm{k}}{ }_{\mathrm{ijt}}\right)
$$

where Imports ${ }^{\mathrm{k}}{ }_{\text {jit }}$ denotes country $\mathrm{j}$ 's imports of product $\mathrm{k}$ from country $\mathrm{i}$ in year $\mathrm{t}$ and Exports denotes the corresponding exports from $\mathrm{i}$ to $\mathrm{j}$ as recorded in the source country.

In our empirical analysis, we aim to explain the observed variation in trade gaps. Fisman and Wei (2007) highlight that, for some product categories, discrepancies in trade statistics reflect extra-legal activities and thus are associated with measures of corruption; we examine the effect of various determinants on trade gaps for all types of products. In particular, we apply the following very general regression framework:

$$
\operatorname{Gap}_{\mathrm{ijt}}^{\mathrm{k}}=\alpha+\beta \mathrm{X}_{\mathrm{it}}+\gamma \mathrm{M}_{\mathrm{jt}}+\delta \mathrm{P}_{\mathrm{ijt}}+\phi \mathrm{Z}_{\mathrm{t}}^{\mathrm{k}}+\varepsilon_{\mathrm{ijt}}^{\mathrm{k}}
$$

where $\mathrm{X}_{\mathrm{it}}$ is a vector of exporter-specific variables that may be correlated with the reporting gap (such as, for instance, corruption), $\mathrm{M}_{\mathrm{jt}}$ is a corresponding set of importer-specific attributes, $\mathrm{P}_{\mathrm{ijt}}$ collects various pair-specific variables (such as, for instance, bilateral distance as a proxy for transportation costs), $\mathrm{Z}$ is a set of product-specific controls (including, for instance, the tariff rate in the destination country), and $\varepsilon$ is a well-behaved residual. We estimate this equation using conventional OLS with year effects, computing standard errors that are robust to clustering.

Relevant country-specific attributes we consider include the level of corruption, the level of economic development, country size and landlockedness. Fisman and Wei (2007) argue that smuggling is more prevalent in countries with corrupt bureaucracies. More specifically, they argue that hiding exports should be easier in a country where it is customary to bribe government officials than in countries where export controls are strictly enforced. As a result, corruption in the source country should be associated with a larger underreporting of exports, thereby widening trade gaps in pair-wise trade statistics. Similarly, though working in the opposite direction (that is, reducing the trade gap), the incentive to properly declare imports is lower when it is relatively easy to persuade customs officials in the destination 
country to disregard the law. In addition, smuggling may be related to a country's level of economic development. Poor countries often have a less effective customs administration; they also produce less reliable official statistics. Moreover, low income may force people into illegal activities. The geographic size of a country may be another proxy for the effectiveness of border controls, since large countries may find it more difficult to enforce trade restrictions. To control for the effect of shipping costs on differences in matched partner trade statistics, we include a dummy variable for landlockedness. Most landlocked countries face a cost disadvantage in international trade, having to cope with the costs of overland transport to neighboring ports and the costs of crossing of at least one additional international border; see Radelet and Sachs (1998). In addition, we include two country-pair specific measures of transportation costs that are standard in the 'gravity' model of trade: the bilateral distance between the two trading partners, and a dummy variable for sharing a common land border. Finally, we enter some measures of product-specific characteristics, such as the applied tariff and the value-to-weight ratio. Low levels of trade protection possibly imply fewer incentives for misreporting; smuggling may be particularly attractive for products with high value-toweight ratios.

Our data is mainly taken from standard sources. In line with previous work, we use the United Nations Comtrade database to obtain exports and imports data at the 4-digit (HS) product level. The database contains detailed (annual) trade statistics reported by statistical authorities of close to 200 countries or territories and standardized by the UN Statistics Division; we examine the records of shipments to the five largest importing nations in the world (United States, Germany, China, United Kingdom and Japan). ${ }^{3}$ At the 4-digit level, there are more than 1,200 product categories. We use the most recent commodity classification (HS-2002); the data are available for five years, covering the period from 2002 to 2006 .

Our measure of corruption is taken from the World Bank's Worldwide Governance Indicators project; see Kaufmann, Kraay, and Mastruzzi (2007). This project combines various variables into an aggregate "control of corruption" score; the score lies between -2.5 and 2.5, with higher scores corresponding to better outcomes (i.e., a less corrupt bureaucracy). As a check, we also use the Corruption Perceptions Index from Transparency International; see http://www.transparency.org. Other data are mainly obtained from the World Bank's

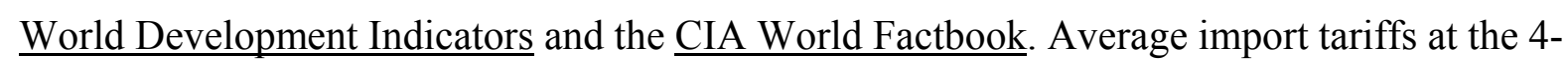

\footnotetext{
${ }^{3}$ See Table I.8 of the WTO's International Trade Statistics 2007, available at http://www.wto.org/english/res_e/statis_e/its2007_e/its07_world_trade_dev_e.pdf.
} 
digit level are provided by the UNCTAD/WTO International Trade Centre (and obtained from http://www.macmap.org). A data appendix describes the variables and sources in more detail.

\section{Empirical Results}

We begin by exploring the full sample of annual country pair-specific trade differences at the 4-digit product level. For illustration, Table 1 lists the five largest (percentage) discrepancies in bilateral trade by importer. Interestingly, a few empirical regularities already emerge from this rough tabulation. For instance, most experiences where recorded import values strongly exceed corresponding exports appear to be concentrated in one single product category, 'petroleum oils, crude' (HS code 2709). As Yeats (1978) notes, this discrepancy is often due to problems in valuing petroleum, and the frequent diversion of petroleum exports from its original destination en route. For other product categories, in contrast, export values (despite disregarding transportation costs) are considerably larger than imports in mirror statistics; these categories include 'other aircraft (for example, helicopters, aeroplanes), spacecraft' (8802), 'cruise ships, excursion boats, ferry-boats, cargo ships, barges and similar vessels for the transport of persons or goods' (8901) and 'gold (including gold plated with platinum)' (7108). A possible explanation is that, especially for bulky items with low-frequency trading, the time lag between exportation and importation may be of particular importance. Also, to the extent that there is any geographical pattern in misreporting, overinvoicing of exports appears to be a more frequent problem in trade with neighboring countries.

To further analyze the geographical pattern in misreporting, we examine differences in trade gaps across countries in more detail. In particular, we aim to identify countries that consistently understate their exports (and, thus, appear to be particularly prone to smuggling). In a first exercise, we compute for each exporter the average trade gap across all products. Since there may be sizable product-specific differences in reported trade values between the exporting and the importing country, taking the arithmetic mean of these reporting gaps over often hundreds of products is a simple way to (hopefully) identify country-specific differences in trade reporting. Table 2 lists the five countries with the largest average percentage share of missing exports by importer. As shown, we find indeed a strong and consistent mismatch in international trade statistics, with continuous underreporting, for instance, by Equatorial Guinea, Indonesia and the Philippines. More importantly, reviewing the full distribution of exporting countries, it turns out that the extent to which countries tend to misreport exports is broadly similar across trade destinations. The correlation of exporter-specific average trade 
gaps across importing countries is astonishingly high, on the order of about 0.9 . Table 3 reports a set of simple bivariate correlation coefficients; (unreported) Spearman rank correlations provide similar results.

\section{$\underline{4.1 \text { Benchmark results }}$}

To analyze the country pair-specific discrepancies in matched partner trade statistics in more detail, we next apply rigorous econometric techniques. In particular, we are interested in the extent to which gaps in official trade statistics are perhaps the result of illicit trade. Fisman and Wei (2007) argue that, for selected product categories, the difference in recorded trade flows is due to smuggling. For antiquities, they find that the extent of underreporting of exports is closely related to the (perceived) level of corruption in the exporting country. We examine whether this association also holds for the whole range of products traded internationally.

Table 4 presents our benchmark results. In the first column, we report the estimation results for the most basic specification of equation (2); that is, we regress the observed average pair-wise trade gap on our variable of interest, corruption in the exporting country, and add a comprehensive set of importer and year fixed effects. The estimated coefficient on the corruption measure is -1.96 , with a robust standard error of 0.21 . This coefficient is not only consistent with the hypothesis that more corruption (i.e., a lower score) is associated with a broader under-reporting of exports; with a t-statistic of 9.4, the coefficient is also highly significant statistically. Moreover, the effect is economically large; a better corruption rating by one index point is associated with a lower trade gap by about 2 percentage points, thereby reducing the discrepancy in corresponding trade figures by about one-half. The estimated coefficient is even slightly larger in magnitude than the analogous estimate for antiquities in Fisman and Wei (2007). Also, our default specification fits the data reasonably well, explaining almost 20 percent of the variation in trade gaps. In sum, our results suggest that smuggling activities are not restricted to a small set of products where there is a strong asymmetry in reporting incentives, but rather seem to affect a large range of products dependent on the norms of corruption in the exporting country. 
Table 1: Largest trade gaps, 2004

\section{$\underline{\text { Underreporting of exports }}$}

\begin{tabular}{|c|l|l|l|l|l|l|l|l|l|l|l|l|l|l|}
\hline \multicolumn{10}{|c|}{ Importer: } \\
\hline \multicolumn{10}{|c|}{ USA } & \multicolumn{3}{|c|}{ Germany } & \multicolumn{3}{c|}{ China } & \multicolumn{3}{c|}{ United Kingdom } & \multicolumn{3}{c|}{ Japan } \\
\hline Exp. & Prod. & Gap & Exp. & Prod. & Gap & Exp. & Prod. & Gap & Exp. & Prod. & Gap & Exp. & Prod. & Gap \\
\hline SAU & 2709 & 23.8 & LBY & 2709 & 22.0 & PHL & 8542 & 22.4 & BWA & 7102 & 21.5 & SAU & 2709 & 23.4 \\
\hline VEN & 2709 & 23.7 & GBR & 8803 & 21.2 & AGO & 2709 & 22.3 & SAU & 2710 & 20.6 & QAT & 2709 & 22.4 \\
\hline NGA & 2709 & 23.5 & DNK & 9999 & 21.2 & SAU & 2709 & 22.3 & KWT & 2710 & 20.4 & IDN & 2711 & 22.3 \\
\hline IRQ & 2709 & 22.9 & SAU & 2709 & 20.7 & OMN & 2709 & 22.2 & PHL & 8542 & 20.3 & KWT & 2709 & 22.1 \\
\hline AGO & 2709 & 22.2 & SYR & 2709 & 20.7 & IRN & 2709 & 22.0 & EGY & 2709 & 19.7 & ARE & 2711 & 21.6 \\
\hline
\end{tabular}

\section{$\underline{\text { Overreporting of exports }}$}

\begin{tabular}{|l|l|l|l|l|l|l|l|l|l|l|l|l|l|l|}
\hline \multicolumn{10}{|c|}{ Importer: } \\
\hline \multicolumn{3}{|c|}{ USA } & \multicolumn{3}{|c|}{ Germany } & \multicolumn{3}{|c|}{ China } & \multicolumn{3}{c|}{ United Kingdom } & \multicolumn{3}{c|}{ Japan } \\
\hline Exp. & Prod. & Gap & Exp. & Prod. & Gap & Exp. & Prod. & Gap & Exp. & Prod. & Gap & Exp. & Prod. & Gap \\
\hline DEU & 8901 & -19.9 & CHN & 8901 & -20.3 & HKG & 8703 & -20.8 & USA & 8803 & -21.2 & SWE & 8802 & -18.9 \\
\hline FIN & 8901 & -19.9 & BEL & 0803 & -19.8 & HKG & 4101 & -19.3 & DEU & 8802 & -21.0 & SGP & 2204 & -18.5 \\
\hline PRT & 8802 & -19.2 & AUT & 8901 & -19.7 & HKG & 7108 & -19.2 & HKG & 7108 & -20.8 & SGP & 2208 & -18.0 \\
\hline MEX & 8602 & -19.1 & DNK & 2716 & -19.1 & JPN & 7108 & -18.6 & CAN & 7108 & -20.7 & NZL & 2709 & -17.9 \\
\hline KOR & 8901 & -18.7 & BLR & 2709 & -18.7 & ARE & 9999 & -18.5 & USA & 8802 & -20.7 & BHR & 7604 & -17.6 \\
\hline
\end{tabular}


Table 2: Underreporting of exports by country, 2002-2006

\begin{tabular}{|c|c|c|c|c|c|c|c|c|c|c|c|}
\hline \multicolumn{12}{|c|}{ Importer: } \\
\hline \multicolumn{2}{|c|}{ USA } & \multicolumn{2}{|c|}{ Germany } & \multicolumn{2}{|c|}{ China } & \multicolumn{2}{|c|}{$\begin{array}{c}\text { United } \\
\text { Kingdom } \\
\end{array}$} & \multicolumn{2}{|c|}{ Japan } & \multicolumn{2}{|c|}{ All five importers } \\
\hline Exporter & Gap & Exporter & Gap & Exporter & Gap & Exporter & Gap & Exporter & Gap & Exporter & Gap \\
\hline Libya & 14.5 & $\begin{array}{l}\text { Equatorial } \\
\text { Guinea }\end{array}$ & 12.1 & $\begin{array}{l}\text { Equatorial } \\
\text { Guinea }\end{array}$ & 14.9 & Indonesia & 12.1 & Iraq & 16.3 & $\begin{array}{l}\text { Equatorial } \\
\text { Guinea }\end{array}$ & 12.6 \\
\hline Lesotho & 13.5 & Indonesia & 11.9 & Congo & 13.5 & Lao PDR & 11.5 & $\begin{array}{l}\text { Equatorial } \\
\text { Guinea }\end{array}$ & 14.0 & Indonesia & 12.4 \\
\hline Indonesia & 13.3 & Ukraine & 11.4 & $\begin{array}{l}\text { Dem.Rep. } \\
\text { of Congo }\end{array}$ & 12.7 & Myanmar & 11.5 & $\begin{array}{l}\text { Western } \\
\text { Sahara }\end{array}$ & 13.7 & Philippines & 11.6 \\
\hline Philippines & 12.7 & Philippines & 11.2 & Tchad & 11.8 & $\begin{array}{l}\text { Bouvet } \\
\text { Island }\end{array}$ & 11.4 & Indonesia & 13.2 & Iraq & 11.4 \\
\hline Iraq & 12.5 & $\begin{array}{l}\text { Serbia and } \\
\text { Monte'gro }\end{array}$ & 11.0 & Rwanda & 11.8 & $\begin{array}{l}\text { Falkland } \\
\text { Isds }\end{array}$ & 11.2 & Botswana & 12.8 & $\begin{array}{l}\text { Western } \\
\text { Sahara }\end{array}$ & 11.3 \\
\hline
\end{tabular}

Table 3: Correlation of exporter-specific average trade gaps

\begin{tabular}{|l|l|l|l|l|l|l|}
\hline & USA & Germany & China & UK & Japan & All \\
\hline USA & 1.0000 & & & & & \\
\hline Germany & 0.9245 & 1.0000 & & & & \\
\hline China & 0.8357 & 0.7824 & 1.0000 & & & \\
\hline United Kingdom & 0.9368 & 0.9571 & 0.7986 & 1.0000 & & \\
\hline Japan & 0.9015 & 0.8572 & 0.8963 & 0.8582 & 1.0000 & \\
\hline All 5 importers & 0.9700 & 0.9494 & 0.9120 & 0.9564 & 0.9548 & 1.0000 \\
\hline
\end{tabular}

Notes: 202 observations. 
Table 4: Does exporter corruption matter?

\begin{tabular}{|c|c|c|c|c|c|}
\hline $\begin{array}{l}\text { Corruption (WB) } \\
\text { exporter }\end{array}$ & $\begin{array}{l}-1.96 * * \\
(0.21)\end{array}$ & $\begin{array}{l}-1.89 * * \\
(0.22)\end{array}$ & $\begin{array}{l}-1.47 * * \\
(0.48)\end{array}$ & $\begin{array}{l}-1.41 * * \\
(0.48)\end{array}$ & \\
\hline $\begin{array}{l}\text { Corruption (TI) } \\
\text { exporter }\end{array}$ & & & & & $\begin{array}{l}-0.53^{*} \\
(0.22)\end{array}$ \\
\hline (Log) Distance & & $\begin{array}{l}0.81^{* *} \\
(0.26)\end{array}$ & & $\begin{array}{l}0.62 * \\
(0.26)\end{array}$ & $\begin{array}{c}0.42 \\
(0.28)\end{array}$ \\
\hline $\begin{array}{l}\text { Common border } \\
\text { dummy }\end{array}$ & & $\begin{array}{l}-0.38 \\
(0.74)\end{array}$ & & $\begin{array}{l}-0.52 \\
(0.74)\end{array}$ & $\begin{array}{l}-0.65 \\
(0.72)\end{array}$ \\
\hline $\begin{array}{l}\text { Landlocked } \\
\text { dummy exp'r }\end{array}$ & & $\begin{array}{l}-0.59 \\
(0.74) \\
\end{array}$ & & $\begin{array}{l}-0.65 \\
(0.74)\end{array}$ & $\begin{array}{l}-0.74 \\
(0.80)\end{array}$ \\
\hline $\begin{array}{l}\text { (Log) GDP per } \\
\text { capita exporter }\end{array}$ & & & $\begin{array}{l}-0.65^{*} \\
(0.31)\end{array}$ & $\begin{array}{l}-0.65^{*} \\
(0.31)\end{array}$ & $\begin{array}{l}-0.69^{*} \\
(0.33)\end{array}$ \\
\hline $\begin{array}{l}\text { (Log) Area } \\
\text { exporter }\end{array}$ & & & $\begin{array}{l}-0.51^{* *} \\
(0.10)\end{array}$ & $\begin{array}{l}-0.49^{* *} \\
(0.10)\end{array}$ & $\begin{array}{l}-0.26^{*} \\
(0.13)\end{array}$ \\
\hline Observations & 4774 & 4774 & 4366 & 4366 & 3324 \\
\hline Adj. R2 & 0.17 & 0.18 & 0.25 & 0.26 & 0.20 \\
\hline
\end{tabular}

Notes: OLS estimation. Dependent variable is the average pair-wise trade gap. Importer and year fixed effects included, but not reported. Standard errors robust to clustering by exporter in parentheses. ${ }^{* *}, *$ and \# denote significant at the 1,5 and 10 percent level, respectively. 


\section{$\underline{4.2 \text { Robustness analysis }}$}

In the remaining columns of Table 4 , we present a number of sensitivity checks. We begin our robustness analysis by adding various control variables that may affect the bilateral gap in trade reporting. In column (2), we include various measures for transportation costs. Except for landlockedness, which is found to be associated, if anything, with smaller (instead of larger) trade gaps, the coefficients take on the expected sign; the discrepancy between recorded exports and imports grows with the geographic distance among the trading partners and is smaller for neighboring countries. However, only the distance variable enters the regression significantly different from zero. More importantly, the estimated coefficient on exporter corruption remains virtually unchanged with this extension. In column (3), instead of adding measures of shipping costs, we include potential proxies for smuggling other than corruption. Of these variables, the coefficient on per capita income in the exporting country is indeed negative and significant, indicating that poorer countries tend to understate exports. The negative coefficient on country size, in contrast, implies that trade gaps are on average larger for geographically small exporters, suggesting that possible 'natural' restrictions on the effectiveness of border controls may be of less importance for the observed discrepancies in corresponding trade figures. Reassuringly, our finding of a negative association between exporter corruption and misreporting in trade is again basically unaffected by this extension, though the estimated coefficient is slightly smaller in magnitude. Next, we include the two sets of controls jointly, without much effect. Finally, in the column on the extreme right of Table 4, we replace our World Bank corruption variable with a measure taken from Transparency International. This score is available only for a smaller number of countries. However, we still find a significant negative relationship between corruption in the exporting country and the share of exports that is also recorded in the importing country, perhaps reflecting the high correlation between both corruption ratings; see Figure 1 for a scatter plot. ${ }^{4}$

\footnotetext{
${ }^{4}$ In another (unreported) robustness check, we examine the association between the trade gap and individual components of the World Bank's "Control of Corruption" measure. For 18 of the 22 variables, we obtain a negative coefficient; most of these coefficients are statistically different from zero at conventional levels of significance.
} 
Figure 1: Corruption measures, 2004

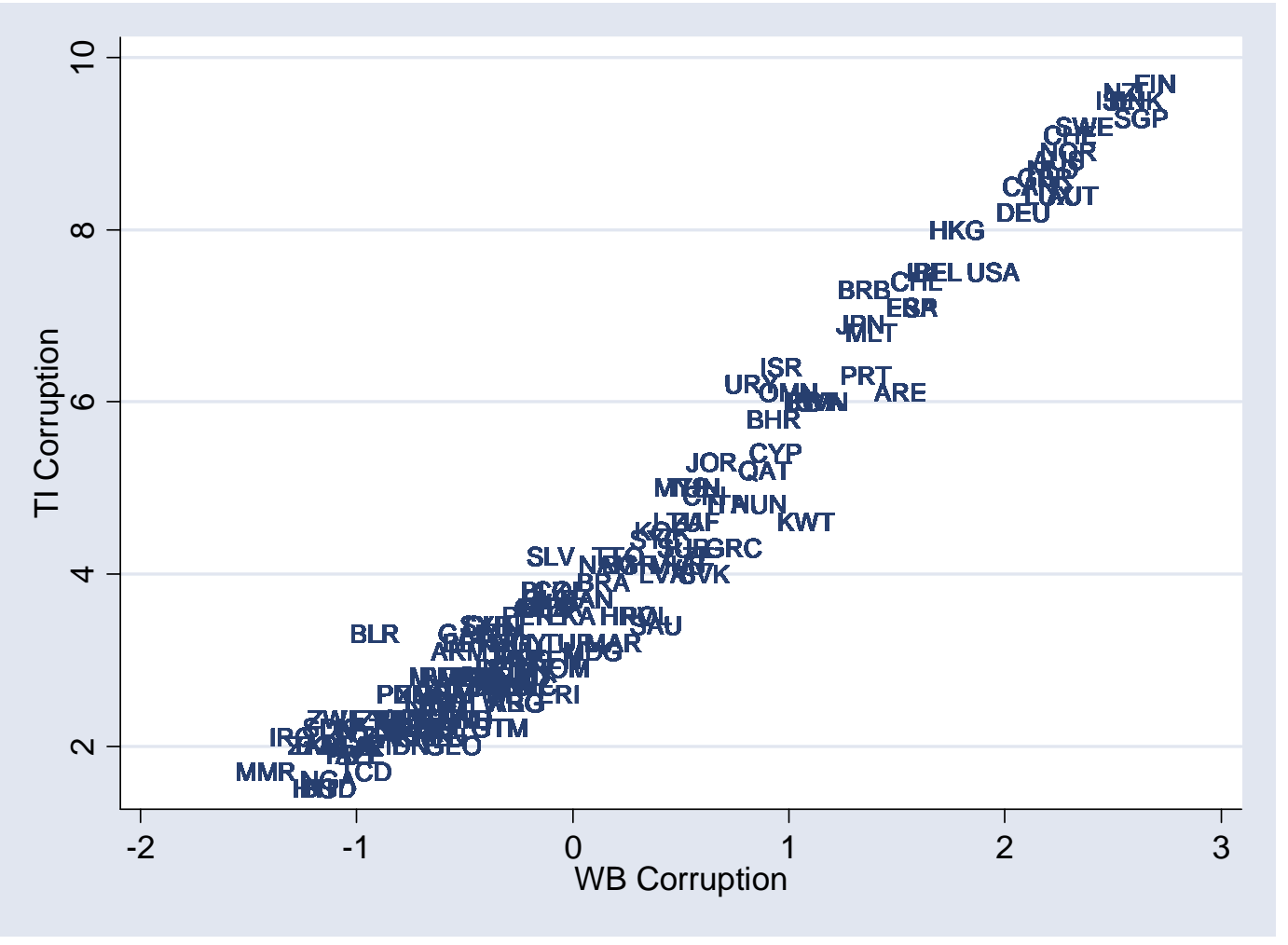


Table 5: Robustness checks for exporter corruption

\begin{tabular}{|l|l|l|l|l|l|l|l|}
\hline & $\begin{array}{l}\text { Corruption } \\
\text { (WB) } \\
\text { exporter }\end{array}$ & Obs. & $\begin{array}{l}\text { Adj. } \\
\text { R2 }\end{array}$ & $\begin{array}{l}\text { Corruption } \\
\text { (TI) } \\
\text { exporter }\end{array}$ & Obs. & $\begin{array}{l}\text { Adj. } \\
\text { R2 }\end{array}$ \\
\hline $\mathbf{2 0 0 2}$ & $\begin{array}{l}-1.63^{* *} \\
(0.48)\end{array}$ & 883 & 0.33 & $\begin{array}{l}-0.36 \\
(0.28)\end{array}$ & 500 & 0.36 \\
\hline $\mathbf{2 0 0 3}$ & $\begin{array}{l}-1.85^{* *} \\
(0.57)\end{array}$ & 891 & 0.27 & $\begin{array}{l}-0.53 \# \\
(0.30)\end{array}$ & 637 & 0.19 \\
\hline $\mathbf{2 0 0 4}$ & $\begin{array}{l}-1.44^{*} \\
(0.64)\end{array}$ & 884 & 0.19 & $\begin{array}{l}-0.52 \# \\
(0.29)\end{array}$ & 703 & 0.14 \\
\hline $\mathbf{2 0 0 5}$ & $\begin{array}{l}-1.34^{*} \\
(0.61)\end{array}$ & 878 & 0.19 & $\begin{array}{l}-0.72^{* *} \\
(0.28)\end{array}$ & 750 & 0.18 \\
\hline $\mathbf{2 0 0 6}$ & $\begin{array}{l}-0.89 \\
(0.60)\end{array}$ & 830 & 0.29 & $\begin{array}{l}-0.35 \\
(0.28)\end{array}$ & 734 & 0.23 \\
\hline $\begin{array}{l}\text { Importer: } \\
\text { USA }\end{array}$ & $\begin{array}{l}-1.44^{* *} \\
(0.54)\end{array}$ & 881 & 0.25 & $\begin{array}{l}-0.57^{*} \\
(0.25)\end{array}$ & 665 & 0.19 \\
\hline $\begin{array}{l}\text { Importer: } \\
\text { Germany }\end{array}$ & $\begin{array}{l}-1.25^{* *} \\
(0.44)\end{array}$ & 883 & 0.34 & $\begin{array}{l}-0.47^{*} \\
(0.21)\end{array}$ & 666 & 0.27 \\
\hline $\begin{array}{l}\text { Importer: } \\
\text { China }\end{array}$ & $\begin{array}{l}-1.31^{*} \\
(0.55)\end{array}$ & 849 & 0.19 & $\begin{array}{l}-0.47^{*} \\
(0.22)\end{array}$ & 665 & 0.16 \\
\hline $\begin{array}{l}\text { Importer: } \\
\text { UK }\end{array}$ & $\begin{array}{l}-1.07^{*} \\
(0.47)\end{array}$ & 877 & 0.26 & $\begin{array}{l}-0.41 \# \\
(0.22)\end{array}$ & 664 & 0.19 \\
\hline $\begin{array}{l}\text { Importer: } \\
\text { Japan }\end{array}$ & $\begin{array}{l}-2.05^{* *} \\
(0.50)\end{array}$ & 876 & 0.31 & $\begin{array}{l}-0.80^{* *} \\
(0.23)\end{array}$ & 664 & 0.25 \\
\hline $\begin{array}{l}\text { Exporter: } \\
\text { OECD }\end{array}$ & $\begin{array}{l}0.20 \\
(0.27)\end{array}$ & 730 & 0.23 & $\begin{array}{l}0.08 \\
(0.11)\end{array}$ & 730 & 0.23 \\
\hline $\begin{array}{l}\text { Exporter: } \\
\text { GDPpc>1k }\end{array}$ & $\begin{array}{l}-1.26 \# \\
(0.67)\end{array}$ & 2900 & 0.24 & $\begin{array}{l}-0.55^{*} \\
(0.27)\end{array}$ & 2347 & 0.16 \\
\hline $\begin{array}{l}\text { Exporter: } \\
\text { Dist.<5000 }\end{array}$ & $\begin{array}{l}-0.28 \\
(0.55)\end{array}$ & 1068 & 0.32 & $\begin{array}{l}0.04 \\
(0.23)\end{array}$ & 869 & 0.30 \\
\hline
\end{tabular}

Notes: OLS estimation. Dependent variable is the average pair-wise trade gap. The specification is similar to column (4) in Table 4; that is, the regression includes the following (unreported) controls: (log) distance, common border dummy, landlocked dummy exporter, (log) GDP per capita exporter, (log) area exporter. Importer and year fixed effects included, but not reported. Standard errors robust to clustering by exporter in parentheses. **, * and \# denote significant at the 1,5 and 10 percent level, respectively. 
Table 5 presents another set of robustness checks. We divide the sample along various lines and report coefficient estimates on exporter corruption, obtained for these subsamples. In particular, we tabulate results for individual years, for separate importing countries, and for various groups of exporting countries. Of these perturbations, only restrictions on the sample of exporting countries included in the empirical analysis have a significant impact on the key coefficient. Not surprisingly, the effect of corruption on the discrepancy in trade statistics disappears for shipments from OECD member countries and trading partners nearby to importers (in our sample), since both groups of countries (often) have low corruption ratings.

In a next experiment, instead of splitting the sample, we now sizably increase the number of observations. More specifically, we substitute the average pair-wise trade gap across all traded products with individual product-specific trade gaps between pairs of countries. Table 6 reports the results. For this extension, the point estimate on the corruption measure decreases in magnitude and even loses statistical significance (though it remains negative). However, it seems generally difficult to explain variation in trade gaps at the product level. Neither the bilateral distance term remains important, nor does the size effect. The empirical fit of our framework is much lower; the adjusted R-squared falls to 0.06 . Moreover, in unreported results, we find that the estimated coefficient on corruption remains negative and significant when the control for per capita income in the exporting country is dropped; that is, for the large sample of individual product-specific trade gaps by exporter, the effect of corruption on the reporting gap seems to work mainly through its correlation with income. Figure 2 graphs the association between per capita income and corruption.

We also explore two reasonable slices of the sample; results are tabulated in the last two columns (on the right) of Table 6. First, we drop observations with negative trade gaps (i.e., where exports exceed imports). Then, we explore a sample where both partner countries, exporter and importer, have a data entry for a trade flow; previously we have imposed a trade value of zero when information from one partner was missing. As shown, both restrictions yield interesting results. Excluding episodes of over-reported exports improves the fit of the regression markedly. With this modification, many coefficients increase in size and significance; the adjusted R-squared jumps to 0.19 . When episodes of missing trade are dropped, the point estimate on corruption becomes of borderline significance (with a p-value of 0.059), while the coefficient on per capita income becomes statistically indifferent from zero. 
Table 6: Product-level evidence for exporter corruption

\begin{tabular}{|c|c|c|c|c|}
\hline & \multicolumn{2}{|c|}{ Full sample } & \multirow{2}{*}{$\begin{array}{l}\text { Gap>0 } \\
-0.45 \\
(0.38) \\
\end{array}$} & \multirow{2}{*}{$\begin{array}{l}\text { Exp \& } \\
\text { Imp >0 }\end{array}$} \\
\hline $\begin{array}{l}\text { Corruption (WB) } \\
\text { exporter }\end{array}$ & $\begin{array}{l}-0.42 \\
(0.37)\end{array}$ & & & \\
\hline $\begin{array}{l}\text { Corruption (TI) } \\
\text { exporter }\end{array}$ & & $\begin{array}{l}-0.07 \\
(0.13)\end{array}$ & & \\
\hline (Log) Distance & $\begin{array}{l}0.20 \\
(0.16)\end{array}$ & $\begin{array}{l}0.14 \\
(0.15)\end{array}$ & $\begin{array}{r}0.29 \# \\
(0.16) \\
\end{array}$ & $\begin{array}{l}0.06 \\
(0.04)\end{array}$ \\
\hline $\begin{array}{l}\text { Common border } \\
\text { dummy }\end{array}$ & $\begin{array}{l}-0.94 \# \\
(0.51)\end{array}$ & $\begin{array}{l}-0.84 \# \\
(0.47)\end{array}$ & $\begin{array}{l}-0.83 \# \\
(0.43)\end{array}$ & $\begin{array}{l}-0.43^{*} \\
(0.19)\end{array}$ \\
\hline $\begin{array}{l}\text { Landlocked } \\
\text { dummy exp'r }\end{array}$ & $\begin{array}{l}-0.67 \\
(0.49)\end{array}$ & $\begin{array}{l}-0.62 \\
(0.48) \\
\end{array}$ & $\begin{array}{l}-0.43 \\
(0.39) \\
\end{array}$ & $\begin{array}{r}0.21 \# \\
(0.11)\end{array}$ \\
\hline $\begin{array}{l}\text { (Log) GDP per } \\
\text { capita exporter }\end{array}$ & $\begin{array}{l}-0.71^{*} \\
(0.28)\end{array}$ & $\begin{array}{l}-0.82^{* *} \\
(0.26)\end{array}$ & $\begin{array}{l}-1.06^{* *} \\
(0.26)\end{array}$ & $\begin{array}{l}-0.03 \\
(0.04)\end{array}$ \\
\hline $\begin{array}{l}\text { (Log) Area } \\
\text { exporter }\end{array}$ & $\begin{array}{l}-0.10 \\
(0.09)\end{array}$ & $\begin{array}{l}-0.03 \\
(0.09) \\
\end{array}$ & $\begin{array}{l}-0.45^{* *} \\
(0.10) \\
\end{array}$ & $\begin{array}{c}0.06 \\
(0.04)\end{array}$ \\
\hline Observations & $1,226,793$ & $1,185,092$ & 686,112 & 729,553 \\
\hline Adj. R2 & 0.06 & 0.06 & 0.19 & 0.02 \\
\hline
\end{tabular}

Notes: OLS estimation. Dependent variable is the pair-wise trade gap at the 4-digit product level. Importer, product and year fixed effects included, but not reported. Standard errors robust to clustering by exporter in parentheses. $* *, *$ and \# denote significant at the 1,5 and 10 percent level, respectively. 
Figure 2: Corruption and income, 2004

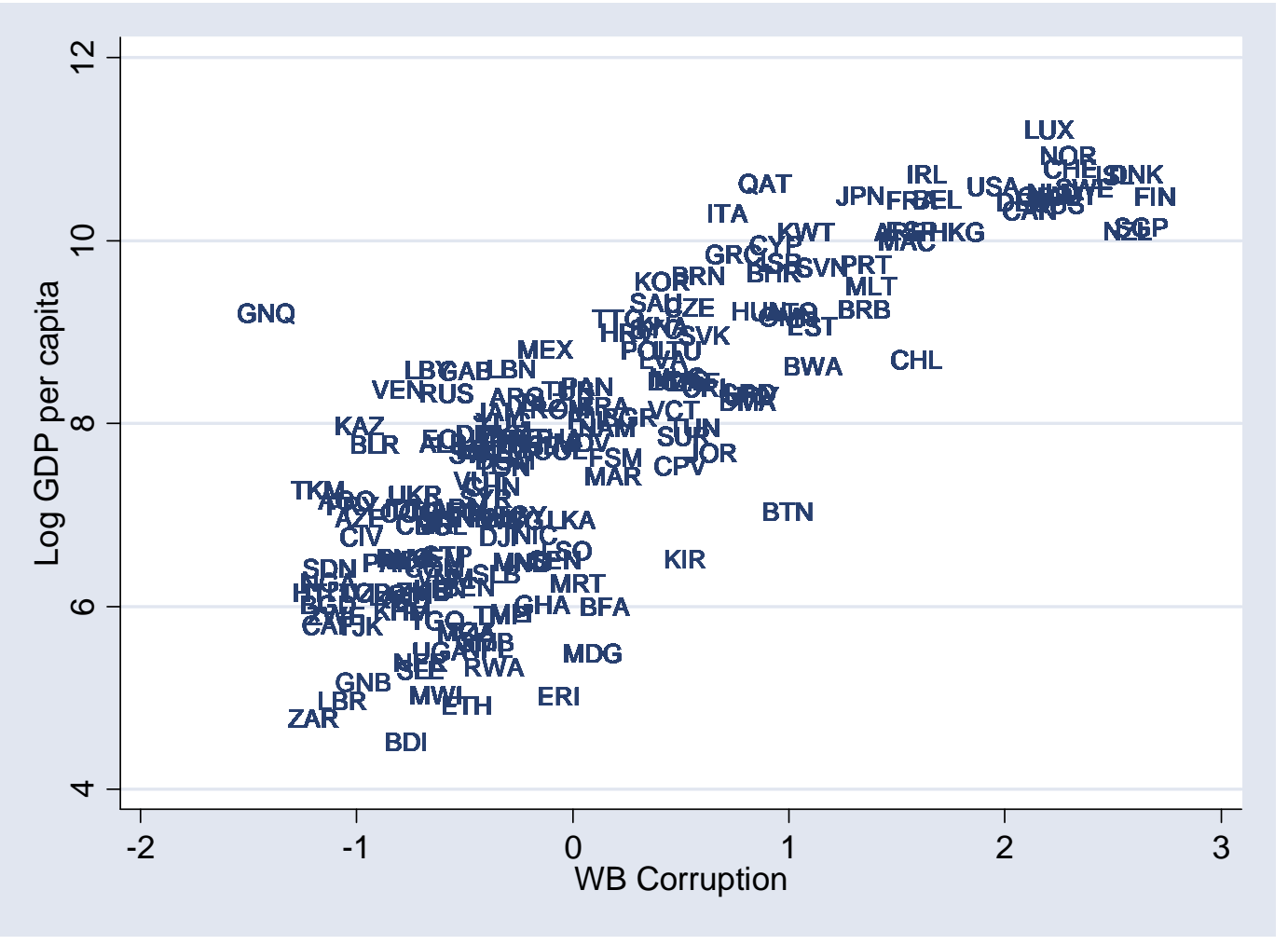




\section{$\underline{4.3 \text { Extensions }}$}

We have also performed a set of other extensions to identify the possible effect of corruption on trade. Table 7 varies our measure of trade gaps. Instead of trade values, we exploit information on the recorded weights and quantities of shipments. For smuggled goods, the choice of the trade measure should be irrelevant for the estimation results; these goods are moved out of the country illegally and unreported. However, if corruption mainly implies that customs officials are bribed to under-invoice export values, the weight and quantity of a good may still be properly recorded at customs which would reduce the estimated impact of corruption. As shown, the coefficient estimates on exporter corruption indeed decrease in magnitude (by about one-third) when we substitute (nominal) trade values by real trade measures. Still, most estimates remain statistically different from zero at conventional levels.

Previous research focuses exclusively on trade restrictions (and the incentives to misreport trade) in the exporting country. A similar reasoning, however, applies for the importing country as well. For certain import sanctions and duties, traders may find it profitable to under-invoice goods (which may or may not have been properly declared in the source country) upon entry. As a result, while corruption in the exporting country is associated with larger trade gaps, we could observe the opposite effect of lower trade gaps for corruption in the importing country. Table 8 provides estimates for importer-specific determinants of pair-wise discrepancies in trade statistics; these estimates are analogues to Table 4. Although our sample covers only five importing countries which have, except for China, almost similar corruption ratings, we find convincing evidence that corruption also matters for imports. ${ }^{5}$ The positive coefficient indicates that a more corrupt bureaucracy in the importing country (that is, a lower corruption index) is associated with a smaller trade gap (and, thus, less recorded imports). The effect disappears once we control for other importer characteristics (especially country size). However, given the small number of importing countries in our sample, this is perhaps not terribly disturbing.

\footnotetext{
${ }^{5}$ In 2006, the World Bank corruption indices were as follows: United States 1.30; Germany 1.78; China -0.53; United Kingdom 1.86; Japan 1.31. The average score for the full sample is zero.
} 
Table 7: Does exporter corruption matter only for values?

\begin{tabular}{|l|l|l|l|l|}
\hline & \multicolumn{2}{|c|}{ Weight } & \multicolumn{2}{c|}{ Quantity } \\
\hline $\begin{array}{l}\text { Corruption (WB) } \\
\text { exporter }\end{array}$ & $\begin{array}{l}-0.89^{*} \\
(0.35)\end{array}$ & & $\begin{array}{l}-0.89^{* *} \\
(0.32)\end{array}$ & \\
\hline $\begin{array}{l}\text { Corruption (TI) } \\
\text { exporter }\end{array}$ & & -0.24 & & $-0.24 \#$ \\
\hline (Log) Distance & $0.36 \#$ & 0.29 & $0.32 \#$ & 0.23 \\
& $(0.19)$ & $(0.21)$ & $(0.17)$ & $(0.18)$ \\
\hline $\begin{array}{l}\text { Common border } \\
\text { dummy }\end{array}$ & -0.34 & -0.45 & -0.47 & -0.43 \\
\hline $\begin{array}{l}\text { Landlocked } \\
\text { dummy exp'r }\end{array}$ & $(0.61)$ & $(0.59)$ & $(0.59)$ & $(0.59)$ \\
\hline $\begin{array}{l}\text { (Log) GDP per } \\
\text { capita exporter }\end{array}$ & -0.51 & -0.70 & -0.39 & -0.47 \\
\hline $\begin{array}{l}\text { (Log) Area } \\
\text { exporter }\end{array}$ & $(0.51)$ & $(0.54)$ & $(0.46)$ & $(0.49)$ \\
\hline \multicolumn{2}{|l|}{$-0.28^{* *}$} & $-0.59 *$ & $-0.41^{*}$ & $-0.54^{*}$ \\
\hline Observations & $(0.07)$ & $(0.24)$ & $(0.20)$ & $(0.21)$ \\
\hline Adj. R2 & 4366 & 3324 & $-0.23^{* *}$ & -0.09 \\
& 0.22 & $0.06)$ & $(0.08)$ \\
\hline
\end{tabular}

Notes: OLS estimation. Dependent variable is the average pair-wise trade gap in the measure that is reported in the first row of the table. Importer and year fixed effects included, but not reported. Standard errors robust to clustering by exporter in parentheses. **, * and \# denote significant at the 1, 5 and 10 percent level, respectively. 
Table 8: Does importer corruption matter?

\begin{tabular}{|c|c|c|c|c|c|}
\hline $\begin{array}{l}\text { Corruption (WB) } \\
\text { importer }\end{array}$ & $\begin{array}{l}0.20^{*} \\
(0.06)\end{array}$ & $\begin{array}{l}0.22 * \\
(0.07)\end{array}$ & $\begin{array}{l}-0.14 \# \\
(0.05)\end{array}$ & $\begin{array}{l}-0.01 \\
(0.08)\end{array}$ & \\
\hline $\begin{array}{l}\text { Corruption (TI) } \\
\text { importer }\end{array}$ & & & & & $\begin{array}{l}-0.01 \\
(0.05)\end{array}$ \\
\hline (Log) Distance & & $\begin{array}{l}0.31 * \\
(0.07)\end{array}$ & & $\begin{array}{l}0.37 * * \\
(0.05)\end{array}$ & $\begin{array}{l}0.37^{* *} \\
(0.05)\end{array}$ \\
\hline $\begin{array}{l}\text { Common border } \\
\text { dummy }\end{array}$ & & $\begin{array}{l}-0.65^{*} \\
(0.21)\end{array}$ & & $\begin{array}{l}-0.53 \# \\
(0.24) \\
\end{array}$ & $\begin{array}{l}-0.53 \# \\
(0.23)\end{array}$ \\
\hline $\begin{array}{l}\text { (Log) GDP per } \\
\text { capita importer }\end{array}$ & & & $\begin{array}{l}0.2{ }^{*} \\
(0.06)\end{array}$ & $\begin{array}{c}0.09 \\
(0.10)\end{array}$ & $\begin{array}{l}0.10 \\
(0.12)\end{array}$ \\
\hline $\begin{array}{l}\text { (Log) Area } \\
\text { importer }\end{array}$ & & & $\begin{array}{l}-0.23 * * \\
(0.01)\end{array}$ & $\begin{array}{l}-0.19^{* *} \\
(0.02)\end{array}$ & $\begin{array}{l}-0.19^{* *} \\
(0.03)\end{array}$ \\
\hline Observations & 5295 & 5287 & 4800 & 4800 & 4800 \\
\hline Adj. R2 & 0.67 & 0.67 & 0.67 & 0.67 & 0.67 \\
\hline
\end{tabular}

Notes: OLS estimation. Dependent variable is the average pair-wise trade gap. Exporter and year fixed effects included, but not reported. Standard errors robust to clustering by importer in parentheses. ${ }^{* *}, *$ and \# denote significant at the 1,5 and 10 percent level, respectively. 
Table 9: Underreporting of exports by product, 2002-2006

\begin{tabular}{|c|c|c|c|c|c|c|c|c|c|c|c|}
\hline \multicolumn{12}{|c|}{ Importer: } \\
\hline \multicolumn{2}{|c|}{ USA } & \multicolumn{2}{|c|}{ Germany } & \multicolumn{2}{|c|}{ China } & \multicolumn{2}{|c|}{$\begin{array}{c}\text { United } \\
\text { Kingdom } \\
\end{array}$} & \multicolumn{2}{|c|}{ Japan } & \multicolumn{2}{|c|}{$\begin{array}{c}\text { All five } \\
\text { importers }\end{array}$} \\
\hline Product & Gap & Product & Gap & Product & Gap & Product & Gap & Product & Gap & Product & Gap \\
\hline 9999 & 10.6 & 7112 & 7.0 & 2709 & 10.7 & 9999 & 7.8 & 2709 & 9.9 & 2709 & 6.9 \\
\hline 9706 & 8.6 & 9704 & 6.7 & 8908 & 9.6 & 8411 & 6.8 & 2619 & 8.9 & 6110 & 5.0 \\
\hline 2709 & 7.2 & 2709 & 6.6 & 2615 & 7.2 & 2620 & 6.5 & 9999 & 8.2 & 4403 & 4.8 \\
\hline 6110 & 6.5 & 2607 & 6.3 & 8601 & 7.0 & 9706 & 6.1 & 2305 & 7.0 & 9999 & 4.8 \\
\hline 6102 & 6.2 & 9302 & 5.8 & 2518 & 6.8 & 7112 & 5.6 & 2711 & 6.5 & 6204 & 4.5 \\
\hline \multicolumn{12}{|c|}{ Position of product code 9706 (1241 products): } \\
\hline 2. & 8.6 & 100. & 3.4 & 1214. & -5.0 & 4. & 6.1 & 191. & 2.3 & 53. & 3.1 \\
\hline
\end{tabular}

Table 10: Correlation of product-specific average trade gaps

\begin{tabular}{|l|l|l|l|l|l|l|}
\hline & USA & Germany & China & UK & Japan & All \\
\hline USA & 1.0000 & & & & & \\
\hline Germany & 0.4347 & 1.0000 & & & & \\
\hline China & 0.1858 & 0.0558 & 1.0000 & & & \\
\hline United Kingdom & 0.3426 & 0.2910 & 0.1581 & 1.0000 & & \\
\hline Japan & 0.4562 & 0.4685 & 0.2251 & 0.2539 & 1.0000 & \\
\hline All 5 importers & 0.7292 & 0.6516 & 0.5376 & 0.6157 & 0.7381 & 1.0000 \\
\hline
\end{tabular}

Notes: 1240 observations. 
In our final exercise, we explore differences in trade gaps across products. Fisman and Wei (2007) argue that one particular (4-digit) product category, antiques of an age exceeding one hundred years (product code 9706), exhibits specific features so that smuggling becomes highly attractive; exports of cultural objects is often strongly restricted, while there are no measurable barriers to imports. We examine, applying the same basic methodology, whether other product categories perhaps display similar features. Table 9 tabulates product categories for which we find the largest reported trade gaps. The top categories appear to differ widely across importers. There are only three product groups for which we observe a large share of underreported exports in more than one destination country. For two of these categories, however, 'petroleum oils, crude' (code 2709) and 'commodities not specified according to kind' (9999), the discrepancy is likely to be unrelated to smuggling. The third top-ranked category is the product category chosen by Fisman and Wei, antiquities. For this group, we report, for comparison, also the rank and the recording gap in other countries. Again, there are sizable differences across importing countries, with China even recording import values that are considerably smaller than worldwide reported exports (i.e., a negative trade gap).

Table 10 reports the pair-wise correlation coefficients that describe the full ranking of products. Similar to our results for exporters, we also find that product-specific trade gaps are significantly correlated across importers, though the correlation coefficients are much lower than before, especially for bilateral pairs that include China.

Still, we aim to characterize differences in trade gaps across products. For instance, one measure for which we explore its association with the discrepancy between recorded imports and exports is the level of import protection, as proxied by the total ad valorem equivalent tariff. To the extent that reporting incentives matter, one would expect that traders report import values more correctly (and, thus, reporting gaps in trade statistics are smaller) when barriers to imports are low. We also exploit two other product-specific measures provided in the UN comtrade database: the weight and quantity of pair-wise trade. Based on these variables, we compute the (average) value-to-weight and value-to-quantity ratios of product-level trade, supposing that high value goods, such as antiquities, are more attractive for smuggling.

Again, we apply a variant of (2) which includes a comprehensive set of either importer- or country pair-specific fixed effects to capture country (pair)-related determinants of trade gaps, including corruption. Table 11 presents the results. We report two sets of estimation results. The first two columns tabulate the estimates for individual product-level trade gaps; the remaining two columns show the results when trade gaps are averaged across 
exporters for individual importers and products. We also report separate results for characteristics in product-level trade recorded by exporting and importing countries, documenting minor differences in statistical significance. Interestingly, we find strong and consistent evidence that trade gaps decrease with the level of import protection. The estimated coefficient on the import tariff is negative and highly significant in all specifications, supporting the view that reporting incentives measurably affect the accuracy of trade statistics. The estimation results for product characteristics are less convincing, possibly as a result of aggregation to the 4-digit product level. Specifically, our findings suggest that trade gaps tend to be larger, if anything, for products with low value-to-quantity ratios. Thus, it appears that underreporting of exports is more prevalent in bulky mass shipments, so that antiquities are an exception rather than the rule, an issue that deserves our future attention.

\section{Conclusions}

Discrepancies in international trade statistics have been frequently analyzed in the past. Statisticians often aim to identify (and quantify) potential reasons for the differences in pair-wise trade statistics to perhaps properly adjust their national trade figures. Economists occasionally exploit the difference between recorded exports and imports as a proxy for bilateral transaction costs.

In this paper, we examine another potential explanation for the observed discrepancy in trade statistics, (illegal) non-declaration. Similar to Fisman and Wei (2007) for antiquities, we find that the reporting gap in bilateral trade is strongly associated with the level of corruption, especially in the source country. In countries with corrupt bureaucracies, it should be easier (and perhaps even common practice) to ignore legal rules and procedures. To the extent that this misbehaviour also affects international trade transactions, our findings suggest that reporting gaps in official trade statistics partly reflect smuggling activities. 
Table 11: Does importer protection matter for product-level trade gaps?

\begin{tabular}{|l|c|l|l|l|}
\hline & \multicolumn{2}{|c|}{$\begin{array}{c}\text { Pair-wise } \\
\text { product-level } \\
\text { trade gaps }\end{array}$} & $\begin{array}{c}\text { Average } \\
\text { importer-specific } \\
\text { product-level } \\
\text { trade gaps }\end{array}$ \\
\hline $\begin{array}{l}\text { Level of } \\
\text { protection imp'r }\end{array}$ & $\begin{array}{l}-0.008^{* *} \\
(0.002)\end{array}$ & $\begin{array}{l}-0.007^{* *} \\
(0.002)\end{array}$ & $\begin{array}{l}-0.013^{* *} \\
(0.004)\end{array}$ & $\begin{array}{l}-0.012^{* *} \\
(0.004)\end{array}$ \\
\hline $\begin{array}{l}\text { Value/weight } \\
\text { importer }\end{array}$ & $\begin{array}{c}4.14 \# \\
(2.42)\end{array}$ & & $\begin{array}{l}-7.91^{* *} \\
(5.87)\end{array}$ & \\
\hline $\begin{array}{l}\text { Unit value } \\
\text { importer }\end{array}$ & 1.89 & & $-3.34^{* *}$ & \\
\hline $\begin{array}{l}\text { Value/weight } \\
\text { exporter }\end{array}$ & $(1.85)$ & & $(7.24)$ & \\
\hline $\begin{array}{l}\text { Unit value } \\
\text { exporter }\end{array}$ & & $1.36^{*}$ & & 2.47 \\
\hline & & $-2.63 * *$ & & $-4.77)$ \\
\hline Observations & 804,452 & 733,507 & 25,192 & 29,067 \\
\hline Adj. R2 & 0.39 & 0.11 & 0.06 & 0.05 \\
\hline
\end{tabular}

Notes: OLS estimation. Dependent variable is reported in the first row of the table. Year fixed effects always included, but not reported. When appropriate, importer or country pair fixed effects are included, but not reported. Standard errors robust to clustering by product in parentheses. ${ }^{* *}, *$ and $\#$ denote significant at the 1,5 and 10 percent level, respectively. 


\section{References:}

Baldwin, Richard. 2006. “The Euro’s Trade Effects,” ECB Working Paper \#594.

Bhagwati, Jagdish. 1964. "On the Underinvoicing of Imports," Bulletin of the Oxford University Institute of Economics and Statistics. 26 (August): 389-397.

Bhagwati, Jagdish. 1967. "Fiscal Policies, the Faking of Foreign Trade Declarations, and the Balance of Payments," Bulletin of the Oxford University Institute of Economics and Statistics. 29 (February): 61-77.

Bhagwati, Jagdish and Bent Hansen. 1973. "A Theoretical Analysis of Smuggling," Quarterly Journal of Economics. 87 (May): 172-187.

Celasun, Merih and Dani Rodrik. 1989. "Debt, Adjustment, and Growth: Turkey" in Jeffrey D. Sachs and Susan M. Collins (eds.) Developing Country Debt and Economic Performance: Country Studies. Chicago: University of Chicago Press.

Dabla-Norris, Era, Mark Gradstein and Gabriela Inchauste. 2008. "What Causes Firms to Hide Output? The Determinants of Informality," Journal of Development Economics. 85 (February): 1-27.

Deardorff, Alan V. and Wolfgang F. Stolper. 1990. "Effects of Smuggling under African Conditions: A Factual, Institutional and Analytic Discussion," Weltwirtschaftliches Archiv. 126 (1): 116-141.

Fisman, Raymond and Shang-Jin Wei. 2007. "The Smuggling of Art, and the Art of Smuggling: Uncovering the Illicit Trade in Cultural Property and Antiques," NBER Working Paper \#13,446.

Hummels, David and Volodymyr Lugovskyy. 2006. "Are Matched Partner Trade Statistics a Usable Measure of Transportation Costs?" Review of International Economics. 14 (February): 69-86.

Kaufmann, Daniel, Aart Kraay and Massimo Mastruzzi. 2007. "Governance Matters VI: Governance Indicators for 1996-2006,” World Bank Policy Research Working Paper \#4280.

Limão, Nuno and Anthony Venables. 2001 "Infrastructure, Geographical Disadvantage, Transport Costs, and Trade," World Bank Economic Review. 21 451-479

McDonald, Donogh C. 1985. "Trade Data Discrepancies and the Incentive to Smuggle: An Empirical Analysis,” International Monetary Fund Staff Papers. 32 (December): 668-692.

Radelet, Steven and Jeffrey Sachs. 1998. "Shipping Costs, Manufactured Exports, and Economic Growth," Harvard University.

Rozanski, Jerzy and Alexander J. Yeats. 1994. "On the (In)accuracy of Economic Observations: An Assessment of Trends in the Reliability of International Trade Statistics," Journal of Development Economics. 44 (June): 103-130. 
Yeats, Alexander J. 1978. "On the Accuracy of Partner Country Trade Statistics," Oxford Bulletin of Economics and Statistics. 40 (November): 341-361.

Yeats, Alexander J. 1990. "On the Accuracy of Economic Observations: Do Sub-Saharan Trade Statistics Mean Anything?” World Bank Economic Review. 4 (May): 135-156. 


\section{Data appendix}

\section{Trade gap}

Difference between log of import value (in current US dollar) recorded in the importing country and the corresponding log of exports (in current US dollar) recorded in exporting country at the 4-digit HS level

Source: computed from UN Comtrade (http://comtrade.un.org)

\section{Corruption (WB)}

Control of corruption score

Source: World Bank Worldwide Governance Indicators project (http://www.governance.org)

\section{Corruption (TI)}

Corruption perceptions index

Source: Transparency International (http://www.transparency.org)

\section{(Log) Distance}

Log of bilateral distance (in $\mathrm{km}$ ) based on coordinates for the geographic center of countries Source: based on data from CIA World Factbook (http://www.cia.gov/library/publications/the-world-factbook/)

\section{Common border dummy}

Dummy variable that takes the value of 1 when two countries share a common land border (and zero otherwise)

Source: based on data from CIA World Factbook

(http://www.cia.gov/library/publications/the-world-factbook/)

\section{Landlocked dummy}

Dummy variable that takes the value of 1 when two countries share a common language (and zero otherwise)

Source: based on data from CIA World Factbook

(http://www.cia.gov/library/publications/the-world-factbook/)

\section{(Log) GDP per capita}

Log of GDP per capita (in current US dollar)

Source: World Bank World Development Indicators

\section{(Log) Area}

Log of surface area (in sq. $\mathrm{km}$ )

Source: World Bank World Development Indicators

\section{Level of protection}

Total ad valorem equivalent tariff at the 4-digit HS level (in \%)

Source: UNCTAD/WTO International Trade Centre (http://www.macmap.org)

\section{Value/weight}

Trade value (in current US dollar) / Net weight (in kg)

Source: computed from UN Comtrade (http://comtrade.un.org)

\section{Unit value}

Trade value (in current US dollar) / Trade quantity (in units)

Source: computed from UN Comtrade (http://comtrade.un.org) 


\section{CESifo Working Paper Series}

for full list see www.cesifo-group.org/wp

(address: Poschingerstr. 5, 81679 Munich, Germany, office@cesifo.de)

2413 Thorsten Upmann, Labour Unions - To Unite or to Separate?, October 2008

2414 Sascha O. Becker and Ludger Woessmann, Luther and the Girls: Religious Denomination and the Female Education Gap in $19^{\text {th }}$ Century Prussia, October 2008

2415 Florian Englmaier and Stephen Leider, Contractual and Organizational Structure with Reciprocal Agents, October 2008

2416 Vittorio Daniele and Ugo Marani, Organized Crime and Foreign Direct Investment: The Italian Case, October 2008

2417 Valentina Bosetti, Carlo Carraro, Alessandra Sgobbi and Massimo Tavoni, Modelling Economic Impacts of Alternative International Climate Policy Architectures. A Quantitative and Comparative Assessment of Architectures for Agreement, October 2008

2418 Paul De Grauwe, Animal Spirits and Monetary Policy, October 2008

2419 Guglielmo Maria Caporale, Christophe Rault, Robert Sova and Anamaria Sova, On the Bilateral Trade Effects of Free Trade Agreements between the EU-15 and the CEEC-4 Countries, October 2008

2420 Yin-Wong Cheung and Daniel Friedman, Speculative Attacks: A Laboratory Study in Continuous Time, October 2008

2421 Kamila Fialová and Ondřej Schneider, Labour Market Institutions and their Effect on Labour Market Performance in the New EU Member Countries, October 2008

2422 Alexander Ludwig and Michael Reiter, Sharing Demographic Risk - Who is Afraid of the Baby Bust?, October 2008

2423 Doina Maria Radulescu and Michael Stimmelmayr, The Welfare Loss from Differential Taxation of Sectors in Germany, October 2008

2424 Nikolaus Wolf, Was Germany ever United? Evidence from Intra- and International Trade 1885 - 1933, October 2008

2425 Bruno S. Frey, David A. Savage and Benno Torgler, Noblesse Oblige? Determinants of Survival in a Life and Death Situation, October 2008

2426 Giovanni Facchini, Peri Silva and Gerald Willmann, The Customs Union Issue: Why do we Observe so few of them?, October 2008 
2427 Wido Geis, Silke Uebelmesser and Martin Werding, Why go to France or Germany, if you could as well go to the UK or the US? Selective Features of Immigration to four major OECD Countries, October 2008

2428 Geeta Kingdon and Francis Teal, Teacher Unions, Teacher Pay and Student Performance in India: A Pupil Fixed Effects Approach, October 2008

2429 Andreas Haufler and Marco Runkel, Firms' Financial Choices and Thin Capitalization Rules under Corporate Tax Competition, October 2008

2430 Matz Dahlberg, Heléne Lundqvist and Eva Mörk, Intergovernmental Grants and Bureaucratic Power, October 2008

2431 Alfons J. Weichenrieder and Tina Klautke, Taxes and the Efficiency Costs of Capital Distortions, October 2008

2432 Andreas Knabe and Ronnie Schöb, Minimum Wage Incidence: The Case for Germany, October 2008

2433 Kurt R. Brekke and Odd Rune Straume, Pharmaceutical Patents: Incentives for R\&D or Marketing?, October 2008

2434 Scott Alan Carson, Geography, Insolation, and Institutional Change in $19^{\text {th }}$ Century African-American and White Stature in Southern States, October 2008

2435 Emilia Del Bono and Daniela Vuri, Job Mobility and the Gender Wage Gap in Italy, October 2008

2436 Marco Angrisani, Antonio Guarino, Steffen Huck and Nathan Larson, No-Trade in the Laboratory, October 2008

2437 Josse Delfgaauw and Robert Dur, Managerial Talent, Motivation, and Self-Selection into Public Management, October 2008

2438 Christian Bauer and Wolfgang Buchholz, How Changing Prudence and Risk Aversion Affect Optimal Saving, October 2008

2439 Erich Battistin, Clara Graziano and Bruno Parigi, Connections and Performance in Bankers' Turnover: Better Wed over the Mixen than over the Moor, October 2008

2440 Erkki Koskela and Panu Poutvaara, Flexible Outsourcing and the Impacts of Labour Taxation in European Welfare States, October 2008

2441 Marcelo Resende, Concentration and Market Size: Lower Bound Estimates for the Brazilian Industry, October 2008

2442 Giandomenico Piluso and Roberto Ricciuti, Fiscal Policy and the Banking System in Italy. Have Taxes, Public Spending and Banks been Procyclical in the Long-Run? October 2008 
2443 Bruno S. Frey and Katja Rost, Do Rankings Reflect Research Quality?, October 2008

2444 Guglielmo Maria Caporale, Antoaneta Serguieva and Hao Wu, Financial Contagion: Evolutionary Optimisation of a Multinational Agent-Based Model, October 2008

2445 Valentina Bosetti, Carlo Carraro and Massimo Tavoni, Delayed Participation of Developing Countries to Climate Agreements: Should Action in the EU and US be Postponed?, October 2008

2446 Alexander Kovalenkov and Xavier Vives, Competitive Rational Expectations Equilibria without Apology, November 2008

2447 Thiess Buettner and Fédéric Holm-Hadulla, Cities in Fiscal Equalization, November 2008

2448 Harry H. Kelejian and Ingmar R. Prucha, Specification and Estimation of Spatial Autoregressive Models with Autoregressive and Heteroskedastic Disturbances, November 2008

2449 Jan Bouckaert, Hans Degryse and Thomas Provoost, Enhancing Market Power by Reducing Switching Costs, November 2008

2450 Frank Heinemann, Escaping from a Combination of Liquidity Trap and Credit Crunch, November 2008

2451 Dan Anderberg, Optimal Policy and the Risk Properties of Human Capital Reconsidered, November 2008

2452 Christian Keuschnigg and Evelyn Ribi, Outsourcing, Unemployment and Welfare Policy, November 2008

2453 Bernd Theilen, Market Competition and Lower Tier Incentives, November 2008

2454 Ondřej Schneider, Voting in the European Union - Central Europe's Lost Voice, November 2008

2455 Oliver Lorz and Gerald Willmann, Enlargement versus Deepening: The Trade-off Facing Economic Unions, November 2008

2456 Alfons J. Weichenrieder and Helen Windischbauer, Thin-Capitalization Rules and Company Responses, Experience from German Legislation, November 2008

2457 Andreas Knabe and Steffen Rätzel, Scarring or Scaring? The Psychological Impact of Past Unemployment and Future Unemployment Risk, November 2008

2458 John Whalley and Sean Walsh, Bringing the Copenhagen Global Climate Change Negotiations to Conclusion, November 2008

2459 Daniel Mejía, The War on Illegal Drugs in Producer and Consumer Countries: A Simple Analytical Framework, November 2008 
2460 Carola Frydman, Learning from the Past: Trends in Executive Compensation over the Twentieth Century, November 2008

2461 Wolfgang Ochel, The Political Economy of Two-tier Reforms of Employment Protection in Europe, November 2008

2462 Peter Egger and Doina Maria Radulescu, The Influence of Labor Taxes on the Migration of Skilled Workers, November 2008

2463 Oliver Falck, Stephan Heblich and Stefan Kipar, The Extension of Clusters: Differencein-Differences Evidence from the Bavarian State-Wide Cluster Policy, November 2008

2464 Lei Yang and Keith E. Maskus, Intellectual Property Rights, Technology Transfer and Exports in Developing Countries, November 2008

2465 Claudia M. Buch, The Great Risk Shift? Income Volatility in an International Perspective, November 2008

2466 Walter H. Fisher and Ben J. Heijdra, Growth and the Ageing Joneses, November 2008

2467 Louis Eeckhoudt, Harris Schlesinger and Ilia Tsetlin, Apportioning of Risks via Stochastic Dominance, November 2008

2468 Elin Halvorsen and Thor O. Thoresen, Parents' Desire to Make Equal Inter Vivos Transfers, November 2008

2469 Anna Montén and Marcel Thum, Ageing Municipalities, Gerontocracy and Fiscal Competition, November 2008

2470 Volker Meier and Matthias Wrede, Reducing the Excess Burden of Subsidizing the Stork: Joint Taxation, Individual Taxation, and Family Splitting, November 2008

2471 Gunther Schnabl and Christina Ziegler, Exchange Rate Regime and Wage Determination in Central and Eastern Europe, November 2008

2472 Kjell Erik Lommerud and Odd Rune Straume, Employment Protection versus Flexicurity: On Technology Adoption in Unionised Firms, November 2008

2473 Lukas Menkhoff, High-Frequency Analysis of Foreign Exchange Interventions: What do we learn?, November 2008

2474 Steven Poelhekke and Frederick van der Ploeg, Growth, Foreign Direct Investment and Urban Concentrations: Unbundling Spatial Lags, November 2008

2475 Helge Berger and Volker Nitsch, Gotcha! A Profile of Smuggling in International Trade, November 2008 